\title{
ecosocial citizenship education: facilitating interconnective, deliberative practice and corrective methodology for epistemic accountability
}

\author{
gilbert burgh $^{1}$ \\ the university of queensland, australia \\ orcid id: https:/ / orcid.org/0000-0003-3183-6348 \\ simone thornton ${ }^{2}$ \\ the university of queensland, australia \\ orcid id: https:/ / orcid.org/0000-0002-9076-1078
}

\begin{abstract}
According to Val Plumwood (1995), liberal-democracy is an authoritarian political system that protects privilege but fails to protect nature. A major obstacle, she says, is radical inequality, which has become increasingly far-reaching under liberal-democracy; an indicator of 'the capacity of its privileged groups to distribute social goods upwards and to create rigidities which hinder the democratic correctiveness of social institutions' ( $p$. 134). This cautionary tale has repercussions for education, especially civics and citizenship education. To address this, we explore the potential of what Gerard Delanty calls 'cultural citizenship' as an alternative to the disciplinary citizenship that permeates Western liberal discourse. Cultural citizenship emphasises citizenship as communication and continual learning processes, rejecting the idea of citizenship as a fixed set of cultural ideals, norms or values defined and enforced by liberal society's legal, political and cultural institutions, including education and 'citizenship training'. However, we contend that a critical first step, essential to democratic correctiveness, is to clear away obstacles created by the privileging of a dominant epistemic position. We conclude that Plumwood's philosophy alongside John Dewey's work on democracy and education provide a theoretical framework for effective democratic inquiry aimed towards interconnective, deliberative practice and corrective methodology for epistemic accountability.
\end{abstract}

keywords: ecosocial citizenship; cultural citizenship; epistemic accountability; democratic correctiveness; epistemic violence.

educação para cidadania eco-social: facilitando práticas interconectivas e deliberativas e a metodologia corretiva para responsabilização epistêmica

\section{resumo}

De acordo com Val Plumwood (1995), a democracia liberal é um sistema político autoritário, que protege privilégios mas falha em proteger a natureza. Um obstáculo importante, diz ela, é a desigualdade radical, cujo alcance se tornou inacreditavelmente longo sob a democracia liberal; um índice da "capacidade dos grupos privilegiados de distribuir bens sociais verticalmente e de criar uma rigidez que esconda a corretividade democrática das instituições sociais" (p. 134). Este conto cautelar tem repercussões para a educação, especialmente a educação cívica e para a cidadania. Para resolver isso, exploramos o potencial do que Gerard Delanty chama de "cidadania cultural" como uma alternativa à cidadania disciplinar que permeia o discurso liberal ocidental. A cidadania cultural enfatiza a cidadania como comunicação e processos contínuos de aprendizagem, rejeitando a ideia de cidadania como um conjunto fixo de ideais culturais, normas ou

\footnotetext{
1 E-mail: g.burgh@uq.edu.au

2 E-mail: s.thornton@uq.edu.au
} 
ecosocial citizenship education: facilitating interconnective, deliberative practice and corrective methodology for epistemic accountability

valores definidos e impostos pelas instituições legais, políticas e culturais da sociedade liberal, incluindo educação e "formação cidadã". No entanto, afirmamos que um primeiro passo crítico, essencial para a correção democrática, é eliminar os obstáculos criados pelo privilégio de uma posição epistêmica dominante. Concluímos que a filosofia de Plumwood, juntamente com o trabalho de John Dewey sobre democracia e educação, fornece um arcabouço teórico para a investigação democrática efetiva voltada para a prática interconectiva e deliberativa e a metodologia corretiva para a responsabilização epistêmica.

palavras-chave: cidadania ecossocial; cidadania cultural; responsabilização epistêmica; corretividade democrática; violência epistêmica.

educación para la ciudadanía ecosocial: facilitar la interconexión, la práctica deliberativa y la metodología correctiva para la responsabilidad epistémica.

\section{resumen}

Según Val Plumwood (1995), la democracia liberal es un sistema político autoritario que protege los privilegios pero no protege la naturaleza. Un obstáculo importante, dice, es la desigualdad radical, que se ha extendido cada vez más en la democracia liberal; un indicador de "la capacidad de sus grupos privilegiados para distribuir bienes sociales hacia las clases altas y para crear rigideces que dificultan la corrección democrática de las instituciones sociales" (p. 134). Esta advertencia tiene repercusiones en la educación, especialmente en educación cívica y ciudadanía. Para abordar esta cuestión, exploramos el potencial de lo que Gerard Delanty llama "ciudadanía cultural" como una alternativa a la ciudadanía disciplinaria que impregna el discurso liberal occidental. La ciudadanía cultural enfatiza la ciudadanía como procesos de comunicación y aprendizaje continuo, rechazando la idea de ciudadanía como un conjunto fijo de ideales, normas o valores culturales definidos y aplicados por las instituciones legales, políticas y culturales de la sociedad liberal, incluida la educación y la "capacitación en ciudadanía". Sin embargo, sostenemos que un primer paso crítico, esencial para la corrección democrática, es eliminar los obstáculos creados por el privilegio de una posición epistémica dominante. Concluimos que la filosofía de Plumwood junto con el trabajo de John Dewey sobre democracia y educación proporciona un marco teórico para una investigación democrática efectiva orientada hacia la interconexión, la práctica deliberativa y la metodología correctiva para la responsabilidad epistémica.

palabras clave: ciudadanía ecosocial; ciudadanía cultural; responsabilidad epistémica; correctividad democrática; Violencia epistémica. 
ecosocial citizenship education: facilitating interconnective, deliberative practice and corrective methodology for epistemic accountability

\section{introduction}

In her paper, 'Has democracy failed ecology? An ecofeminist perspective', Val Plumwood (1995) concludes that it is 'not democracy that has failed ecology, but liberal democracy that has failed both democracy and ecology' (p. 134). She argues that 'the escalation of the processes responsible for ecological degradation, despite the great citizen effort that has gone into challenging them in democratic polities, therefore represents an alarming failure' (p. 135) of the current liberaldemocratic political systems. Liberal-democracy, she argues, is an authoritarian political system, with its 'military systems organised around protecting privilege which control so much of the planet' (p. 136), and as a result, fails to protect nature. She does not, however, see democracy per se as inherently authoritarian.

The superiority of democracy to other systems in detecting and responding to ecological problems would seem to lie largely, then, in its capacity for adaptation and correction. So in order to discover why democracy is failing, we must now ask which political features of democracy contribute to and what forms hinder its capacity for correction? (p. 137, italics added)

For Plumwood, a major obstacle that hinders this capacity is radical inequality, which, she claims, 'is both itself a hindrance to correctiveness and a key indicator of other hindrances to societal correctiveness' (p. 137). She contends that radical inequality, which has become increasingly far-reaching under liberaldemocracy, is an indicator of 'the capacity of its privileged groups to distribute social goods upwards and to create rigidities which hinder the democratic correctiveness of social institutions' (p. 134). In the case of liberal-democracy, economic privilege drives this story of stark separation; the separation of the ecologically privileged from the ecologically underprivileged, of those deemed close to nature from those thought of as above or superior to nature. It is a 
ecosocial citizenship education: facilitating interconnective, deliberative practice and corrective methodology for epistemic accountability

separation that generally plays out along the lines of colonial violence and is a continuation of colonisation, as will be explained. ${ }^{3}$

For a considerable range of environmental ills resulting from the institutions of accumulation, then, some redistribution and insulation is possible. It is the privileged members of a society who can most easily insulate themselves from these forms of environmental degradation; toxic wastes and occupations can be directed to poorer residential areas (including Third World destinations), and if privileged suburbs, regions or territories become noisy, degraded or polluted, the privileged can buy places in more salubrious environments. (p. 138)

The story of the rich separated from the poor is a familiar one-the 'salubrious environments' of the economically privileged contrast starkly with those of the economically disadvantaged. This privileging is not restricted to economic class but to gender and ethnicity also. Plumwood says of this divide that ' $[\mathrm{t}] \mathrm{he}$ most oppressed and dispossessed people in a society are those who are made closest to the condition of nature, who are made to share the same expendable condition as nature' (p. 139). Anthropocentrism, androcentrism and ethnocentrism all combine to confer privilege in colonial cultures. Part of this dispossession is the dispossession of the voices of entire groups of people. A political voice is denied to those who are considered 'Other'; no political provisions are made for their perspectives, for their knowledge, to be heard in an existentially meaningful way, that is, in a way that leads to a correction of their situation. For all intents and purposes, they are denied full epistemic legitimacy within the dominant mainstream discourse; educationally, culturally, socially, and politically. The silencing of Indigenous peoples and Othering of their culture in Australia, both historically and today, is an example we will return to later. ${ }^{4}$ Globally, those in the most disadvantaged positions are the ones most likely to suffer the greatest effects of anthropogenic climate change, ${ }^{5}$ social and economic injustice, and other social and ecological ills, while at the same time, having the

\footnotetext{
${ }^{3}$ For more on the topic of present instantiations of colonisation see: Moreton-Robinson (2015), Wolfe (2006), Smith, Tuck \& Yang (2019).

4 See Watson (2011, 2014), Thornton \& Burgh (2019).

5 See Olsson et. al. (2014), Chapter 13 of the 2014 IPCC report, 'Livelihoods and poverty', which 'is devoted to exploring poverty in relation to climate change, a novelty in the IPCC' (p. 798). Its addition reflects growing global recognition and concern over the effects of climate change on those already economically and ecologically disadvantaged.
} 
least political recourse to address such issues. Plumwood argues that the liberal political system suffers from a communication problem that makes ecological and social justice correction difficult, if not impossible. Often those closest to environmental systems, those with the most to gain from their preservation and the greatest understanding of the problems they face, are unable to protect the environment and must resort to means of resistance to protect themselves.

Plumwood's cautionary tale of liberal-democracy has repercussions for education, especially civics and citizenship education. In this article, we imagine an alternative conception of democracy - as an associated form of living - that does not rest on a foundation of stark separations. To this end, our proposal is a response to Plumwood's call for a radical democratic alternative to liberaldemocracy to facilitate democratic correctiveness, which she argues is the hallmark of democracy. We explore the potential of what Gerard Delanty (2003) calls 'cultural citizenship' as an alternative to the disciplinary citizenship that permeates Western liberal discourse. Cultural citizenship emphasises citizenship as communication and continual learning processes, rejecting the idea of citizenship as a legal status or fixed set of cultural ideals, norms or values defined and enforced by liberal society's legal, political and cultural institutions, including education and 'citizenship training'. While we concur with Delanty on the potential of cultural citizenship, we contend that a critical first step, essential to democratic correctiveness, is to clear away obstacles created by epistemic violence. ${ }^{6}$

Epistemic violence is a harm caused by the totalising of knowledge, the privileging of a single epistemic position to the determent of all others. Colonisation, a central system of power that dominates the surrounding land and all within it, including Indigenous peoples who have been 'sociohistorically constructed through first world Western knowledge systems that are ontologically and epistemologically grounded in differentiation' (Moreton-Robinson, 2015, p. vii), can be viewed through the lens of epistemic violence. As can patriarchal and patrilineal societies, in which men are primarily in roles of political leadership,

\footnotetext{
${ }^{6}$ A term we adapt from Gatyai Spivak (2003) and elaborate on; see Thornton \& Burgh (2017).
} 
ecosocial citizenship education: facilitating interconnective, deliberative practice and corrective methodology for epistemic accountability

moral authority, social privilege and control of property. In both cases, epistemic violence is structural and the foundation for built environments; materially, spatially and culturally constructed surroundings intended for human habitation. ${ }^{7}$ It is an environment that has undergone large scale changes, creating a habitat that has a bias toward the epistemic, ontological and axiological frameworks of the dominant culture, to such an extent that all humans and other species 'must adapt to that environment to survive, rather than a mutual adaptation of diverse habits and habitats' (Burgh \& Thornton, 2017, pp. 8-9) that allows space for democratic correctiveness, which, in turn, can reconstruct the environment materially, spatially and culturally, that is inclusive, not just for humans, but for non-human animals and ecological systems.

We turn to cultural citizenship and examine why it struggles for a foothold in a landscape shaped by epistemic violence. To address this issue, while avoiding the problem of democracy becoming subservient to a normative theory of citizenship, and, therefore, to the governmentalisation of citizenship as a learning process, we draw on Dewey's thoughts on democracy and education, which provide a theory of democracy whereby the citizen plays an active role in the construction of democracy. We argue that Dewey's conception of citizenship is 'repoliticized by democracy, allowing us to speak of democratic citizenship' (Delanty, 2000, p.36), rather than confining citizenship to membership of society or the bearer of rights which informs democratic theory. More specifically, it is a theory of democracy whereby citizenship is seen as communicative citizenship with a democratic aim; that is, of construction of the relationship between society and the state. By shifting the emphasis away from a model of citizenship that rests on political foundationalism, in the sense that a given model of democracy can be justified only by an appeal to self-evident truth about human nature, natural rights or other pre-political or normative foundations, toward an emphasis on democratic engagement, citizenship itself becomes the means for mitigating

\footnotetext{
7 The built environment includes landscape architecture, e.g., parkland, botanic gardens and green belts, which are designed to give the impression that they are natural environments. Even though landscape architecture involves investigating social, ecological and geological aspects of landscapes, its aim is to achieve desirable aesthetic, environmental or social-behavioural results for humans.
} 
epistemic violence though reconstructing politics, and thus, essential to democratic correctiveness.

We conclude that Plumwood's philosophy alongside John Dewey's work on democracy and education provide a mutually supportive theoretical framework for effective democratic inquiry aimed towards interconnective, deliberative practice and corrective methodology for epistemic accountability.

\section{cultural citizenship as an educative process}

While there remains much contention over definitions of democracy and disagreement over competing models, the term 'democracy' is now generally characterised by two principles of power relations between individuals and institutions in society: (1) citizen control over public decision-making, and (2) distributive equality in the exercising of citizen decision-making. Many models of democracy fit within this broad definition, but this is so because, historically, democracy is a social and political construct that has been shaped by diverse ideologies under very specific social circumstances. In its liberal form, democratic institutions reaffirm majority rule and have, in practice, broadly failed to strengthen these principles, as evidenced by increasing social divisions, such as those outlined by Plumwood above. Consequently, democracy fails to live up to its own rhetoric. The existing dominant conception of democracy is underpinned by an adversarial conception of politics, and is, therefore, antagonistic toward democratic ways of life, that is, it fails to facilitate democratic correctiveness. On democratic correctiveness, Plumwood (1995), notes that democratic

systems that are able to articulate and respond to the needs of the least privileged should be better than less democratic systems that reserve participation in decision-making for privileged groups. This is because radical inequality is both itself a hindrance to correctiveness and a key indicator of other hindrances to societal correctiveness. (p. 137)

Liberal-democracy also 'rests on the assumption that without representative government, free and fair elections at regular and frequent intervals, and mandate and merit as rationales for governance, there is no democracy' (Burgh, 2010, p. 60). But this view results in serious ethical failures. In representative systems of democracy 'power is concentrated on a small number of 
ecosocial citizenship education: facilitating interconnective, deliberative practice and corrective methodology for epistemic accountability

politicians and high-level bureaucrats and citizen input into policy is minimal, political accountability is low and elected representatives susceptible to vested interests, misconduct and corruption' (Burgh, Field \& Freakley, 2006, p. 91). Moreover, liberal-democracy is underpinned by a conception of citizenship that 'is reduced to a formalistic relationship to the state as one of rights and duties' (Delanty, 2000, p. 22); a legal status bound up in pre-political notions of liberty, the private sphere, and consumer rights, to the neglect of the public sphere as the location of citizenship. With the shift toward neoliberal politics since the 1970s, an 'emphasis on decentralisation, deregulation, and privatisation, the concept of citizenship has once again become strongly linked to the market' (Burgh 2010 p. 60 ), and, thus, the citizen as consumer. These factors can be seen as 'rigidities which hinder the democratic correctiveness of social institutions' (Plumwood, 1995, p. 134), insofar as these rigidities result from the concentration of power on a small number of politicians and high-level bureaucrats which protects privilege.

A neglected dimension in developing capacities for democratic correctiveness is education, particularly the idea of citizenship as a learning process. According to Delanty (2003), the dominant liberal discourse on citizenship has become indistinguishable from 'disciplinary citizenship' that permeates official policy documents, 'in which learning is reduced to citizenship classes and formal membership of the polity' (p. 597). He refers to this as the governmentalisation of citizenship as a learning process, to indicate a governmental discursive coding of citizenship as a cognitive competence:

In this discourse, citizenship is constructed by codes, categories and modes of classification that reflect a governmental strategy into which the individual as citizen is inserted. Thus, the immigrant [be]comes [sic] a citizen by participating in a discourse that redefines social relations according to fairly fixed categories. What is noticeable in this is that the language of citizenship and learning is taken over by the state and defined according to a set of rigid categories. (p. 599)

In terms of education, this governmentalisation of citizenship is characterised by governmental discourse that has remained within rights discourse and formal membership of the polity with emphasis on equality over difference and advocates the idea of a common public culture regardless of ethnic 
groupings. Critics claim that such measures dilute non-Western values in favour of Western values and advocate cultural assimilation or exclude worldviews that do not sit well within the framework non-liberal values (Clarke, Coll, Dagnino \& Neveu, 2014; Kapai, 2012). Consequently, the introduction of civics and citizenship education as a compulsory part of the secondary school curriculum tends to emphasise the teaching of putative common civic values and the workings of institutions such as the electoral and criminal justice system. In other words, learning processes are reduced to formal learning, and the assumption is that what needs to be learned is the official values of the polity as interpreted by public officials; all other values and knowledge are subsumed. It also assumes that individual learning processes convert into a collective learning outcome. However, '[c]ollective learning processes operate on quite different levels and the relation between individual and collective learning is complex' (p. 599) and, therefore, cannot be assumed. As citizenship is a process undertaken both individually and collectively, understanding collective learning processes is paramount to understanding citizenship, whereby citizens learn about and shape society.

Delanty contrasts disciplinary citizenship with 'cultural citizenship', which makes a greater connection between learning and citizenship, as a collective discursive learning process that occurs on individual, group and institutional levels. According to Delanty, '[a]ny discussion about learning must begin with the recognition that learning occurs on different levels and that there are quite different kinds of learning. The way individuals learn is quite different from the way societies learn' (p. 600). Cultural citizenship moves away from 'the fixed, rule learning model implicit in disciplinary citizenship' (p. 600) toward a dynamic view of citizenship 'conceived of in terms of learning processes that have a developmental and transformative impact on the learning subject' (p. 605). By learning, Delanty means

cognitive processes that allow information to be combined in different ways to provide a subject-individual, a group, a society-to have a capacity for action. Learning may therefore entail learning to learn and thus a certain reflexivity [...] In this way, learning entails empowerment or the capacity of a subject to 
reproduce itself. To be emphasized, then, is the processual nature of learning, which is an open process defined in movement rather than in finality. This view of learning suggests a cultural dimension to it; that is, culture as a making or a doing. Learning involves agency on the part of the learning subject. The cognitive structures operate in learning processes connect different frames and codes. Learning is thus a cultural process of creation and construction. (pp. 600-601)

Delanty's attention to learning processes emphasises learning as: (1) an individual biography, (2) an intersubjective conduit, occurring as interpersonal cultural narratives that provide interpretations of the world, for social construction, by which individual learning is translated and coordinated into collective learning, and (3) cultural learning that eventually becomes embodied in social institutions. The relation between the three levels is complex, but he thinks can be summed up as: process, connectivism, development, construction, and transformation (pp. 601-602). Such learning can change normative and epistemic frameworks that provide structures to guide social action and social change. Such changes in learning result from a constructivist process of communicative links between 'common experiences, cognitive processes, forms of cultural translation and discourses of empowerment' (p. 602), which he holds can arise out of both ordinary experiences and 'major crises and catastrophes such as the experience of victimhood or injustice. It appears that an essential dimension of the cognitive experience of citizenship is the way in which individual life stories are connected with wider cultural discourses' (p. 602). Cultural citizenship not only enhances the individual's cognitive competencies but has the potential to bring about collective learning.

Unlike disciplinary citizenship, which rigidly views citizenship as a formal body of knowledge or proficiency, cultural citizenship is imbued with mechanisms for democratic correctiveness because citizenship occurs in communicative situations and, therefore, connects individuals to their society through sustained narratives, consisting of memories, shared values and experiences, which speaks to Plumwood's concerns of separation from Other. Similarly, Delanty points to a lack of shared language to communicate dissatisfaction as contributing to increased social ills and pathologies; without 
such a language, people and groups may experience a loss of recognition from feeling alienated, and, thus, lack a sense of belonging as citizens which can lead to political decisions based on fear or ignorance and to racism or xenophobia. However, he does not address colonisation, a major source of cultural rigidities, which perpetuates xenophobia. On the issue of education's ability to address xenophobia, Delanty has the following to say:

Much of the problem of widespread xenophobia is due to failures in learning mechanisms and can be counteracted by encouraging active, cultural citizenship that can lead to a transformation of the cultural models that constitute collective learning. My argument is the future of citizenship as a strategy to oppose xenophobia will have to cultivate what might be called a new language, or cognitive structures for learning. (p. 603)

While a shared language is important, we argue that the ways in which colonisation is perpetuated in education, society and politics must be taken into account if we are to create a 'new language' that breaks with the epistemic violence of the past and present. We concur with Delanty regarding the necessity of 'generating a more discursive citizenship' (p. 603), however, to overcome alienation the emphasis must be on democratic correctiveness, which requires the capacity for multiple cultures to flourish. This is especially important, and lacking, if we consider that political systems are often founded on the annihilation and replacement of epistemic frameworks with unwelcome epistemologies; colonisation being a relevant example. Australia's history of colonisation is a clear case of the imposition of one culture onto another, beginning with the extension of British sovereignty to Australia in 1788, and the eventual passing of the Commonwealth of Australia Constitution Act by British Parliament. The Act saw Australian colonies become a federation in 1901, an event that is often seen as merely political, and all too easily relegated to the past, rather than being viewed as the imposition of ongoing epistemic and ontological structures (Wolfe, 2006; see also Thornton \& Burgh, 2017, 2019). These structures continue to dominate and control the social and political landscape and shape the cultural identity of Australia to this day, including the educational landscape.

Education as a site of cultural reproduction is often steeped in assimilation, which we argue is a form of epistemic violence, and an obstacle to correctiveness. 
ecosocial citizenship education: facilitating interconnective, deliberative practice and corrective methodology for epistemic accountability

Epistemic violence, then, must be addressed if cultural citizenship is to be achieved. The lack of a shared language Delanty speaks of can be viewed as, what Fricker (2007) calls, a hermeneutical gap, insofar as there is a gap in collective interpretive resources which disadvantages groups when it comes to making sense of their social experiences. This gap, when a result of a colonial built environment, causes epistemic violence to individuals and communities. Thus, to respond to and correct such violence requires focusing attention on 'experiences that do not fit the dominant story' (Plumwood, 2002, pp. 12-13), that is, the experiences of the individuals and the communities that have been silenced through colonisation, past and present. This work is imperative if we are to cultivate a new language or shared values which include the values and voices of those who do not easily fit into the dominant narrative. In the next section we look to John Dewey to provide possible pathways towards a form of cultural citizenship that mitigates epistemic violence.

\section{an inquiring society}

The importance of Dewey's thoughts on democracy and education cannot be exaggerated. Although writing in the early 1900s, his influence still resonates today, and there is much we can still learn from him. As Philip Cam (2000) aptly asserts:

When it comes to the connections between philosophy, democracy and education we could hardly find a more rewarding philosopher than John Dewey. Not only does the quest for democracy animate the whole vast canvas of his work, but Dewey also has an abiding concern with both education and the social value of philosophy, which makes the intersection between philosophy, democracy and education Dewey's home ground. Nor is Dewey's work lacking in contemporary social relevance. His vision of the democratic society as one that is democratic throughout the whole of its social fabric, and which thereby supplies everyday life with greater opportunities for human fulfilment, remains vital today, when democratic societies are still popularly conceived of merely as those that enjoy a certain form of government. (p. 158)

Our task, however, will be to explore Dewey's assumptions about democratic society and offer a proposal for the adaptation of his idea of an 
inquiring society, achieved through education premised on his notion of reconstruction.

According to Dewey (1916), reconstruction of knowledge and experience requires a reciprocal relationship between habit and habitat. Indeed, he asserted that ' $[t]$ he variety of peoples and environment, their contrast with familiar scenes, furnishes infinite stimulation' (p. 212). When an organism is no longer able to affect its habitat, but must only adapt to it, the habitat becomes dominant-a built environment in the sense we describe. The dominant habitat can render existing habits obsolete, and subsequently individuals, groups and even cultures can become alienated as these habits are no longer suited to the environment. To put it in terms of liberal-democracy, liberal discourse creates the habitat, which backgrounds and nullifies the habits of certain humans and natural processes. In doing so, it has the potential to not only restrict habits but create obstacles to further changes and reconstruction of the habitat on which humans depend. The built environment, in this case, the dominant liberal-democratic habitat, constructs obstacles to democratic correctiveness, and, thus, to the development of an inquiring society.

Education as a foundational building block of Western liberal democracy tends to be cast in terms of the individual. It focuses on equipping individuals with the skills and knowledge to define and pursue their own goals and to contribute to society as full-fledged, autonomous citizens. However, in pluralistic societies not all groups support the development of autonomous individuals. Many Indigenous groups are ontologically relationally oriented, and the notion of an abstract individual, which is the hallmark of Western liberal-democracies, can be seen to weaken or challenge a group's communal relations and ways of being. In terms of cultural continuity, survival is threatened, and formal or stateprovided liberal education is often active in blocking attempts for renewal. Undeniably, for all peoples-small groups, larger societies and nation-statescontinuing survival relies on educational processes, whether formal or informal. As Dewey (1916) announced in Democracy and Education, 'in its broadest sense' education is the means of the 'social continuity of life' (p. 3). It is noteworthy that 
ecosocial citizenship education: facilitating interconnective, deliberative practice and corrective methodology for epistemic accountability

Dewey does not emphasise education as equipping 'individuals' for life. The purpose of education then is the 'social continuity of life'.

To Dewey, education is not preparation for life, but is life itself, to which he added that it is a form of associated living. In this sense, education is a form of cultural renewal, a learning process responsible for the continuity of what it means to be part of culture; it can, therefore, encompass the values, the ethics, the language, the land, the law, and the lore. Regarding Indigenous peoples in Australia, Irene Watson (2012) points out that 'Indigenous law, philosophy and knowledges are core to our Indigenous past and they still hold our present worlds together, promising a future for First Nations peoples even in the face of colonialism which has done much to marginalise First Nations' (p. 508).

To sever education from culture is to commit violence that is not confined to any specific time, place or physical act, but is ongoing violence in the form of knowledge subjugation-epistemic violence-that deprives people from effectively participating in a pluralist society and from contributing to its diversity and, thus, continues the genocidal project of assimilation. Mary Graham succinctly describes the absurdity underpinning, what Wolfe (2006) calls, the logic of elimination, by which multiple aspects of the continual life of one group of people are denied by another:

If one true way is posited, sooner or later individuals or groups are inclined to ideologise it; rigid thinking then follows (or vice versa), and the formation of groups of "true believers", chosen people, sects, religions, parties, etc cannot be far behind. Historically, different groups/individuals have assumed that there is only one absolute answer to the question of existence, usually their own. If this assumption is accepted, then logically there must be thousands, if not millions, of potential absolute answers to this age-old question. (Graham, 1999, p. 113)

That a rigidity of thinking drove, and continues to drive, the elimination of life on the Australian continent and others has been extensively argued by scholars from a diversity of disciplines, for example, feminism (Lloyd, 2000), law (Godden, 2012; Watson, 2014), education (Nakata, Nakata, Keech \& Bolt, 2012; Shor \& Freire, 1987), and decolonisation scholarship more broadly (Spivak, 2003; Smith, 2012). Dewey's pragmatist view of the world, which is a naturalistic approach to knowledge as the result of an active adaptation of the human 
organism to its environment, can help to educationally challenge such rigid thinking. His view constitutes a rejection of the dualistic epistemological and metaphysical views of philosophy wherein the universe is static, complete and unchanging. To Dewey, endings are adaptations that signify new beginnings, as he recognised that an end is also a means to yet another end, in a continual process of change; a continual reconstruction. Reconstruction is not progress towards any definitive or known end or final goal, but rather the adaptive ability of the organism and environment. Reconstruction, therefore, is always incomplete, and further problematic situations alter the relationship between the organism and the environment. For humans, it is the relationship between belief-habits and habitat that needs to be a dialectic relationship for cultural citizenship to be effective. Dewey's emphasis on habit and habitat is at the heart of his epistemology. His shift toward a biological concept of experience, and by extension, education, recognises the plasticity of humankind as part of the greater plasticity of nature. Dewey's shift in epistemology equates to a shift in values, that many environmental philososophers have argued is essential to mitigating all forms of environmental degradation. ${ }^{8}$

Dewey was convinced that learning through doing, insofar as we learn from reflecting on our experiences, is the best approach to education. The lessons we gleam from experiences both inside and outside the classroom, shape how we see and interact with others and the world, that is, with our habit and habitat. Moreover, Dewey's emphasis on learning through doing links student's experiences outside of the classroom, their home, neighborhood and local community which is part of what Dewey called the greater community, to that which happens in the classroom. As learning is unavoidable, from the earliest beginnings of a child's life through family, friends, and community, until they start school and are influenced further by friendships, teachers, and both the set and hidden curriculum, attention to the relationship between schooling and life, both inside and outside the classroom, is vital to educating citizens. While being consumers in the greater society is today a part of life for most people, attention

\footnotetext{
8 For an argument for the need for a new environmental ethic, see Leopold (2013), Mathews (1996), Routley (1973).
} 
also needs to be on dissolving the dualism between consumer and citizen. This is especially vital in relation to environmental education if we are to address Plumwood's contention that liberal-democracy has, through its failure to be corrective, failed both ecology and democracy.

\section{ecosocial citizenship as a learning process}

If Plumwood is right in arguing that it is the chains of liberalism that tie our governments to ecological devastation, then it is citizens who must be the ones to cut them. To educate citizens fit for the task, we must strive beyond the construction of the liberal individual. To instantiate the kind of ecologically and culturally responsive democracy that Plumwood and Dewey advocate, we must education toward a new kind of citizen and to do so, we argue, requires democratic education, rather than education for democracy.

Whereas education for democracy focuses on the acquisition of knowledge and skills as a means to improve the capacity of future citizens to exercise competent autonomy, democratic education recognises the social role of schooling as that of reconstruction and that children and young people have an integral role to play in shaping democracy. (Burgh, 2014, p. 31, italics added)

Education for democracy - which includes teaching or instilling values such as respect for liberal institutions; civics or political education aimed at the reinforcement of political knowledge, namely, liberal-democratic values, principles and procedures; and political literacy, which places emphasis on political competence - may serve political leaders who have a vested interest in promoting a particular conception of citizenship, as 'a means for enabling individuals, organisations, and nations to meet the challenges of an increasingly competitive world to the neglect of involving people in a continuing process of education aimed at self-actualisation and a learning society' (Burgh, 2014, p. 24). In doing so, education for democracy fails to promote the correctiveness required for effective democracy. Democratic education, on the other hand, is inherently corrective as emphasis is on reconstruction through dialogic inquiry. In this sense, democracy is an educational process, a form of praxis, and not something to educate toward. 
Emphasis also needs to be on environmental education grounded, in the Deweyan sense, in authentic social problems that require 'students to draw simultaneously on knowledge and methods from multiple disciplines in an interconnected manner in order to work through such problems', rather than being subject to curriculum hierarchy, 'which maintains that supposedly abstract school subjects, like mathematics and physics, are more valuable than subjects associated with concrete experience, practicality and the body, such as physical education and vocational subjects' (Bleazby, 2015, p. 671). This is important because, if learning is unavoidable, so, too, is identity formation; what we learn forms our identity, both our individual and national identity. Indeed, the task of education, implicitly or explicitly, is identity formation and nation building through curriculum, hidden or otherwise. Therefore, the relationship between self and environment, belief-habit and habitat, needs to be the focus of education if we are to dissolve the dualism of consumer and citizen and understand how the integral relationship between self and environment affects us. In other words, liberal identity - the rational autonomous individual who judges what the good life is for them - is but one kind of identity among many, yet it is the dominant identity perpetuated through educational emphasis on self-development and skills to compete in a world of other individuals seeking resources. The task of environmental education is to extend the boundaries of self, beyond the liberal individual, to experiences that point to the need to revise our 'conception of the self and its relation to the nonhuman other, opposition to oppressive practices, and the abandonment and critique of cultural allegiances to the dominance of the human species and its bonding against non-humans' (Plumwood, 2002, p. 205) and those humans classed as non-human.

Educational emphasis, therefore, needs to be on ecosocial citizenship as a learning process that enhances the collective learning capacity of society; a form of cultural citizenship with a focus on 'the inclusion of multiple knowledge systems, not as topics or issues to critique, but as starting points for inquiry' (Thornton \& Burgh, 2017, p. 62), in which 'Western contemporary technosciences, rather than 
being taken as definitional of knowledge, rationality, or objectivity, should be treated as varieties of knowledge systems' (Graham, 2014, p. 6).

Failing to include varieties of knowledge systems, either through text, or the knowledge of teachers, students, parents, and members of the wider community, fails to interrupt the dominant narrative, leaving it unquestioned-or, to reiterate Freire's words, 'leaving the dominant ideology in peace'. In short, the teacher needs to be aware of the limiting capacity of epistemic violence to create a safe space for varieties of knowledge systems so intellectual freedom can flourish for all. (Thornton \& Burgh, 2017, p. 62)

To facilitate such learning, then, requires going beyond Delanty's understanding of cultural citizenship with its emphasis on the role of communication and learning processes in which culture and citizenship are connected in a cognitive relationship.

\section{conclusion}

Plumwood's criticism of liberal-democracy failing both ecology and democracy cannot be ignored. In addition, the accumulating evidence of anthropogenic climate change demands a change in our consumer and citizen habits. This puts pressure on democracy to have the capacity for correctiveness to bring about change; to facilitate interconnective, deliberative practice and corrective methodology for epistemic accountability - to not exclude epistemic frameworks currently subordinate to the dominant logic of liberal-democratic governmentality and discourses that perpetuate radical inequalities.

As a society we can no longer ignore the repercussions of colonisation, especially the silencing of Indigenous understanding of human relations to land and country in the face of anthropogenic climate change. To address these concerns will require re-emphasising the relationship between belief-habits and habitats and, inevitably, the reshaping of democracy. Such a change requires a move away from rugged individualism toward cultural citizenship that emphasises citizenship as a learning process. We have argued in favour of democratic education as a way of reconstructing citizenship as a dialectic process, which enables the democratic correctiveness of social institutions. In this sense, citizenship is an educative process that is life itself; an associated form of living 
rather than a set of rights and duties. As such, citizens have an integral role to play in shaping democracy. In the case of schooling, children would then practice democracy as an ongoing process of collaborative inquiry that aims at selfcorrection as a fundamental aspect of inquiring communities. Pedagogically, this provides a means to distribute epistemic power in the classroom and opportunities for each child to exert epistemic influence, which is a constitutive condition of non-domination, insofar as each child can effect a change in the epistemic situation, which that child or others are in, through sharing beliefs or persuading others.

\section{references}

Bleazby, J. (2015). Why some school subjects have a higher status than others: The epistemology of the traditional curriculum hierarchy. Oxford Review of Education, 41(5), 671-689.

Burgh, G. (2010). Citizenship as a learning process: Democratic education without foundationalism. In D.R.J. Macer \& S. Saad-Zoy (Eds.), Asian-Arab philosophical dialogues

on globalization, democracy and human rights (pp. 59-69). Bangkok: UNESCO, Regional Unit for Social and Human Sciences in Asia and the Pacific.

Burgh, G. (2014). Democratic pedagogy. Journal of Philosophy in Schools, 1(1), 22-44.

Burgh, G., \& Thornton, S. (2017). The democratic habitat: Promoting peace education. Refereed paper presented at Philosophical Inquiry with Children: Family resemblances, XVIII International Council for Philosophical Inquiry with Children (ICPIC) Conference, Formación del Profesorado Faculty, Cantoblanco campus, Universidad Autonoma de Madrid, Spain (pp. 1-19). 28 June-1 July 2017.

Burgh, G., Field, T., \& Freakley, M. (2006). Ethics and the community of inquiry: Education for deliberative democracy. South Melbourne: Thomson.

Cam, P. (2000). Philosophy, democracy and education: Reconstructing Dewey. In I-S Cha (Ed.), Teaching philosophy for democracy (pp. 158-181). Seoul: Seoul University Press.

Clarke, J., Coll, K., Dagnino, E., \& Neveu, C. (2014). Recentering citizenship. Disputing citizenship (pp. 9-56). Bristol: Policy Press.

Delanty, G. (2000). Citizenship in a global age: Society, culture, politics. Philadelphia: Open University Press.

Delanty, G. (2003). Citizenship as a learning process: Disciplinary citizenship versus cultural citizenship. International Journal of Lifelong Education, 22(6), 597-605.

Dewey, J. (1916). Democracy and education: An introduction to the philosophy of education. New York: Free Press/Macmillan.

Fricker, M. (2007). Epistemic injustice power and the ethics of knowing. Oxford; New York: Oxford University Press.

Godden, L. (2012). Native title and ecology: Agreement-making in an era of market Environmentalism. In J.K. Weir (Ed.), Country, native title and ecology (pp. 105-134). ACT: ANU E Press and Aboriginal History Incorporated.

Graham, M. (1999). Some thoughts about philosophical underpinnings of Aboriginal world views. Worldviews: Global Religions, Culture and Ecology, 3(2), 105-118. 
ecosocial citizenship education: facilitating interconnective, deliberative practice and corrective methodology for epistemic accountability

Kapai, P. (2012). Developing capacities for inclusive citizenship in multicultural societies: The role of deliberative theory and citizenship education. Public Organization Review: A Global Journal, 12(3), 277-298.

Leopold, A., (2013). A sand county almanac $\mathcal{E}$ other writings on ecology $\mathcal{E}$ conservation (Library of America ; 238). New York: Library Of America.

Lloyd, G. (2000). No one's land: Australia and the philosophical imagination. Hypatia, 15(2), 26-39.

Mathews, F. (1996). Ecology and democracy. Portland: Frank Cass.

Moreton-Robinson, A. (2015). The white possessive: Property, power, and indigenous sovereignty. Minneapolis: University of Minnesota Pressp

Nakata, N.M., Nakata, V., Keech, S., \& Bolt, R. (2012). Decolonial goals and pedagogies for indigenous studies. Decolonization: Indigeneity, education $\mathcal{E}$ society, 1(1), 120-140.

Olsson, L., Opondo, M., Tschakert, P., Agrawal, A., Eriksen, S.H., Ma, S., Perch, L.N., \& Zakieldeen, S.A. (2014). Livelihoods and poverty. In C.B. Field, V.R. Barros, D.J. Dokken, K.J. Mach, M.D. Mastrandrea, T.E. Bilir, M. Chatterjee, K.L. Ebi, Y.O. Estrada, R.C. Genova, B. Girma, E.S. Kissel, A.N. Levy, S. MacCracken, P.R. Mastrandrea \& L.L. White (Eds.), Climate Change 2014: Impacts, Adaptation, and Vulnerability. Part A: Global and Sectoral Aspects. Contribution of Working Group II to the Fifth Assessment Report of the Intergovernmental Panel on Climate Change (pp. 793-832). Cambridge; New York: Cambridge University Press.

Plumwood, V. (1995). Has democracy failed ecology? An ecofeminist perspective. Environmental Politics, 4(4), 134-168.

Plumwood, V. (2002). The Ecological Crisis of Reason. London; New York: Routledge.

Routley, R. (1973). Is there a need for a new, an environmental, ethic? Proceedings of the XVth World Congress of Philosophy, Varna, Bulgaria, 17-22 September (pp. 205-210). Varna: Sofia Press.

Shor, I., \& Freire, P. (1987). A pedagogy for liberation. South Hadley: Bergin \& Garvey Publishers.

Smith, L.T. (2012). Decolonizing methodologies: Research and indigenous peoples, second edition. London: Zed Books.

Smith, L.T., Tuck, E., \& Yang, W. (Eds.) (2019). Indigenous and decolonizing studies in education: Mapping the long view (pp. 1-24). New York: Routledge.

Spivak, G.C. (2003). Can the subaltern speak? Die Philosophin, 14(27), 42-58.

Thornton, S., \& Burgh, G. (2017). Making peace education everyone's business. In C-C. Lin \& L. Sequeira (Eds.), Inclusion, diversity and intercultural dialogue in young people's philosophical inquiry (pp. 55-65). Rotterdam: Sense Publishers.

Thornton, S., \& Burgh, G. (2019). Growing up with philosophy in Australia: Philosophy as cultural discourse. In G. Burgh \& S. Thornton (Eds.), Philosophical Inquiry with Children: The development of an inquiring society in Australia (pp. 335-249). Abingdon: Routledge.

Watson, I. (2011). Aboriginal(ising) international law and other centres of power. Griffith Law Review, 20(3), 619-640.

Watson, I. (2014). Re-centring first nations knowledge and places in a Terra Nullius space. AlterNative: An International Journal of Indigenous Peoples, 10(5), 508-520.

Wolfe, P. (2006). Settler colonialism and the elimination of the native. Journal of Genocide Research, 8(4), 387-409.

received in: 12.05 .2019

accepted in: 02.06.2019 